\title{
ENFORCING THE EUROPEAN SEMESTER: THE POLITICS OF ASYMMETRIC INFORMATION \\ IN THE EXCESSIVE DEFICIT AND MACROECONOMIC IMBALANCE PROCEDURES
}

\author{
James Savage, University of Virginia \& \\ David Howarth, University of Luxembourg ${ }^{1}$
}

Please note: This is the authors' pre-print version. It differs from the final published version of the article. Please access and reference the published version:

Savage, J. D. \& Howarth, D. (2018) 'Enforcing the European Semester: the politics of asymmetric information in the excessive deficit and macroeconomic imbalance procedures', in Journal of European Public Policy, 25, 2, pp. 212-230.

\begin{abstract}
The European Semester is an information-driven surveillance system that relies upon budgetary and economic statistics collected from the European Union's (EU) member states and analyzed by the European Commission. This is true for both the Excessive Deficit Procedure and the Macroeconomic Imbalance Procedure. This paper employs Principal-Agent theory to analyze the politics of asymmetric information and how this is addressed in the EDP and MIP. This study explores how the statistical requirements of Six Pack have been enforced by the Commission and ECOFIN to strengthen the EDP, even as the statistical integrity of the MIP received less protection. The paper focuses on the case of the Spanish Valencia's misrepresentation of statistics that provoked the first financial sanction in the history of Economic and Monetary Union, as well as efforts by the Commission to strengthen the reliability of MIP statistics.
\end{abstract}

1 The authors wish to thank the FNR (Luxembourg National Research Fund) for financial support through the Inter-Mobility programme (grant Inter/Mobility/2015/9874103/MEESEU/ Howarth). 


\section{INTRODUCTION}

The European Semester was created in response to the Greek and euro crises to strengthen and deepen the fiscal and economic coordination of the European Union. At the center of the Semester is an information-driven surveillance process that relies heavily upon fiscal and economic information collected from the member states and analyzed by the European Commission (Commission). This is true for both the Stability and Growth Pact's (SGP) Excessive Deficit Procedure (EDP) and the Macroeconomic Imbalance Procedure (MIP). The EDP relies on deficit and debt statistics to determine member state compliance and the application of sanctions. The MIP relies on eleven headline and twenty-eight auxiliary statistical indicators as part of the EU's economic alert mechanism to determine whether to activate InDepth Reviews and the application of sanctions (Essi and Stiglbauer 2011; Moschella 2014). As stated in the Six Pack, 'The availability of fiscal data is crucial to the proper functioning of the budgetary surveillance framework of the Union,' and 'Reliable statistical data is the basis for the surveillance of macroeconomic imbalances' (Council Directive 2011/85/EU; Council Regulation 1174/2011). Both procedures function in the context of asymmetrical information relationships where supranational organizations must obtain statistical information generated by the member states that may ultimately serve as the basis for corrective sanctioning through the EDP and the Excessive Imbalance Procedure (EIP).

Despite the significance of the Semester's asymmetric information for EU economic governance, with few exceptions, little scholarly attention has been paid as to how the rules governing the Semester's procedures for administering these data affect the political relations between EU institutions and the member states (Savage 2005; Schelkle 2009; Mabbett and Schelkle 2014; 
Gandrud and Hallerberg 2016). This paper addresses this deficiency in the literature by analyzing through a Principal-Agent (PA) framework the politics of asymmetric information in the EDP and MIP. As a result of the Greek and euro crises, member states agreed to longstanding Commission initiatives to change the information and date gathering requirements of the surveillance process from one characterized by a fire-alarm to a police patrol system of monitoring. The layering of new rules and administrative practices significantly expanded the scope of economic EU surveillance in the form of the Semester (Chang 2013a; Verdun 2015). In the context of the Semester's extensive information requirements, this paper first explores how the Commission and the Economic and Financial Affairs Council (ECOFIN) required member state compliance with the statistical provisions of the Semester to strengthen the EDP. For the first time in the history of the Economic and Monetary Union (EMU), a member state has been subjected to the ultimate sanction: a financial penalty. This fine was imposed not for a member state's violation of the EDPs deficit and debt thresholds, but for the failure to provide accurate statistical information to the Commission. This paper next examines a similar, but less successful initiative by the Commission to strengthen the accuracy of its MIP statistics. Because of these decisions taken by both principals and agents, in the context of ensuring the credibility of member state statistics the EDP resembles an enhanced police patrol monitoring system while the MIP resembles the less rigorous fire alarm approach to surveillance.

Finally, this paper places the politics of EDP/MIP asymmetric information within the context of the current debate over the rise of intergovernmentalism since the onset of the euro crisis. As anticipated by PA theory, the creation and enforcement of the EU's surveillance procedures reflect the ebb and flow of power relationships between multiple principals and supranational 
agents that are dynamic and contested over time. Most recently, the member states through the European Council have reasserted their authority over EU economic governance as a result of the euro crisis (Puetter 2012; Bickerton et al 2014; Hodson 2013; Schimmelfennig 2015). The euro crisis has also witnessed the rise of the European Parliament (EP) as an additional principal in the surveillance process (Dinan 2014; Rittberger 2014). This paper argues that this intergovernmentalist turn occurred even as ECOFIN approved the Commission's entrepreneurial initiatives for enhanced authority over the member states in the effort to control asymmetric information (Ellinas and Suleiman 2011; Chang 2013b; Bauer and Becker 2014a, 2014b; Dehousse 2015; Savage and Verdun 2015). Yet, at the same time, as will be shown here, the member states have withheld approval for the Commission's proposed regulation over the quality of MIP statistics that they view as counter to their interests (Conceição-Heldt 2016; Bauer and Becker 2016).

\section{THE DYNAMICS OF PRINCIPAL-AGENT THEORY AND ASYMMETRIC INFORMATION}

This study employs a PA framework to analyze the surveillance relationships between and among member states and EU institutions, especially the Commission. In PA theory, principals delegate authority and functional tasks to agents because of their organizational capacities and technical competencies. PA relationships may be cooperative, but they are frequently contested and even adversarial. Tensions exist because agents often have their own agendas and organizational imperatives that may result in opportunistic behavior that runs counter to the interests and intent of their principals. This opportunistic behavior often takes the form of agency loss in the form of drift and shirking, where agents pursue their own preferences rather 
than those of the principals. Agents possess privileged asymmetric information that they may misrepresent or hide from principals to advice their interests (Kiewiet and McCubbins 1991; Miller 2004). Principals respond to the presence of this asymmetric information asymmetry through monitoring and sanctioning. Classic PA theory expresses a clear preference for the monitoring system that principals should employ to control their agents. The strongest expression of this is found in the difference between 'police patrol' and 'fire alarm' monitoring . PA theorists reason that decentralized fire alarm systems result in fewer transactions costs for principals and are more politically effective than centralized police patrol systems. Where police patrol systems require extensive, burdensome, and costly direct oversight by principals of their agents, fire alarm systems rely upon constituents and vested interests to complain, or sound the alarm, about dysfunctional, unresponsive agents. Although monitoring systems often include elements of the two methods of surveillance, PA theorists argue that 'predominantly' decentralized fire alarm systems result in fewer transaction costs for principals, are more politically effective than centralized police patrol systems, and are more 'likely to secure compliance with legislative goals' (McCubbins and Schwartz 1984).

This paper argues that the classic PA model is inverted in the context of European economic governance. Rather than principals monitoring agents, member state principals delegate to supranational agents the task of monitoring the budgetary and economic behavior of the principals themselves (Schuknecht 2004; Hodson 2009; Chang 2013a; Gren, Howarth, and Quaglia 2015). The member states exercise final authority over their agents in the design and implementation of the surveillance procedure. The member states ultimately determine how intrusively and in what manner the Commission may conduct its monitoring, and in this way 
determine whether the surveillance system reflects a police patrol or fire alarm framework. The principals approve the rules the Commission must enforce, and they ultimately determine whether they themselves should be sanctioned. The Commission may, for example, propose how often and under what circumstance member states should be visited, and whether member state budgets should be audited. Yet these initiatives must be approved by the member states. The principals identify which supranational agents participate in the surveillance procedure, and they adjudicate when multiple agents compete for the right to administer various monitoring tasks, in what constitutes supranational 'bureaucratic politics' (Pollack 1997; Schelkle 2005; Hawkins et al 2006). To promote the integrity of the surveillance procedure, the member states may also delegate discretionary authority to its agents, granting them some of the prerogatives of a trustee (Majone 2001; Tallberg 2002).

The EU's PA relationships are further complicated by the structure of some member state governments, especially those that are extensively federated or jurisdictionally segmented. The Treaty on European Union (TEU) and allied legislation apply to 'general government,' the aggregated levels of government within a member state, not simply the national government. So, for example, in the case of Spain, there are 17 Autonomous Communities (AC), 50 provinces within those communities, and seven of those ACs are considered to be both an $\mathrm{AC}$ and a province. Madrid is one of these single province communities while the AC of Valencia contains three provinces. There are some 5,000 units of government and publicly funded agencies that report budgetary information that eventually constitute Spain's aggregate deficit and debt figures. 
Prior to the euro crisis, the member state principals preferred a monitoring procedure analogous to the fire alarm system. Through the TEU's Article 104(2), its Protocol on the Excessive Deficit Procedure, and Council Regulation 3605/93, the member states delegated to supranational agencies the fiscal surveillance of the EMU. Yet, member states limited the Commission's authority to employ all of the monitoring tools available to conduct a penetrating surveillance of the member states' fiscal actions. First, for example, the TEU's Article 126 limited the Commission's surveillance only 'to identifying gross errors' in the budgetary statistics submitted by the member states in their biannual reports to the Commission. Second, the TEU did not call upon the European Court of Auditors, the one EU institution familiar with analyzing member state budgets, to deploy its auditors to review these budgets. Third, Eurostat, the Commission's statistical agency responsible for certifying the biannual reports was greatly restrained in making country visits and precluded from conducting audits of member state accounts. To a great extent, the surveillance process relied up the fire alarms of external sources, including the media and private rating services such as Moody's to identify egregious member state budgetary activity (Savage 2006).

Furthermore, it is important to recall that sanctions play a critical role in PA theory. Although the process of collecting information itself may produce disciplinary effects through the systematic use of surveillance techniques, the compliance of agents ultimately depends upon the application of meaningful sanctions. In the history of EMU, prior to the Spanish case described in this study, no member state had previously been subjected to a financial penalty, despite widespread noncompliance with the EU's deficit and debt requirements. Member states have instead been sanctioned by a host of soft sanctions that take the form of repeated reports, 
recommendations, and guidelines drafted by the Commission calling for compliance. The softness of these sanctions is exemplified by the Commission's Broad Economic Policy Guidelines issued during the EMU convergence process. This fire-alarm styled arrangement changed in reaction to the economic crises that soon gripped Europe.

\section{THE SIX PACK: CONTROLLING INFORMATION EVASION AFTER THE GREEK AND EURO CRISES}

If PA theorists prefer fire-alarm systems, then why did EU's principals move towards a policepatrol system? The Greek and euro crises served as critical junctures in the evolution of the surveillance process, as previously reluctant member states increasingly strengthened the EU's supranational institutions' centralized police patrol capabilities. The Greek statistical crises of 2004 and 2009, during which Greece submitted false statistics regarding the size of its budget deficit to gain entry into the EMU and that later contributed to the euro crisis, resulted in numerous rules that highlighted the importance of transparent and credible statistics (Savage and Verdun, 2015). As a senior official in Employment Commissioner Marianne Thyssen's Cabinet, to whom Eurostat now reports, noted, 'Greece made countries very determined on making sure the data were correct, and gave Eurostat invasive powers it never would have got otherwise, and that was obvious. ${ }^{1}$ After multiple requests, ECOFIN granted Eurostat auditing powers through Council Regulations 479/2009 and 679/2010. Of the five regulations and one directive that constitute the Six Pack, one regulation and the directive focus on the problem of asymmetric information. Council Regulation 1173/2011 outlines the policing of member states engaged in the 'misrepresentation, whether intentional or due to serious negligence' of government fiscal data. The regulation establishes the basis for detecting, investigating, and financially sanctioning 
duplicitous member state behavior. The Commission is empowered to conduct surveys for 'detecting and exposing' statistical manipulations, and for conducting 'any investigations necessary' if there are indications of statistical manipulation. The regulation permits the Commission to interview anyone involved in the creation of data, if that person agrees to the meeting. Significantly, the regulation authorizes the Commission to recommend that the egregious member state that 'intentionally or by serious negligence misrepresents deficit and debt data' be fined for this violation in a manner that 'shall be effective, dissuasive and proportional to the nature, seriousness and duration of the misrepresentation.' Although the total amount of the fine shall not exceeding .2 percent of the member state's GDP, the reference amount for the penalty shall be equal to 5 percent of the misrepresentation of either the member state's deficit or debt covered by the notification period of the EDP. The Six Pack's provisions soon came into play when the Commission sought sanctions against Spain for the misrepresentation of its EDP statistics.

\section{THE POLITICS OF ASYMMETRIC INFORMATION IN THE EDP: THE CASE OF} VALENCIA

The Valencia case is the first of two analyzed in this study that exemplify how the politics of asymmetric information play a critical role in EU economic governance. In reaction to Greece and the euro crisis, the EU reinforced the Semester in a centralized police patrol-like manner, to the extent that both principals and agents agreed for the first time in EMU history to impose financial penalties against a member state for misrepresenting its data for the EDP's surveillance procedure. 


\subsection{The Institutional Framework of Spanish EDP Reporting}

To appreciate the Valencia case, it is first necessary to understand that the EU's challenge of managing asymmetrical information begins with the TEU's requirement that member states report their fiscal and economic data to Eurostat on a biannual basis, in March and October. These data must be submitted in a manner consistent with the European System of National Accounts (ESA). Eurostat exercises trustee-like authority to interpret the ESA, which is the overall accounting system that harmonizes member state deficit and debt figures and determines their calculation for the EDP and the MIP. The collection and analysis of these data reflect a long chain of interlaced institutional PA relationships within the EU, first emanating from member state approved treaties and secondary rules, through supranational agencies, to the member state national governments, to regional and local government and public units, all of which must be managed effectively to overcome the presence of asymmetric information in the Semester surveillance process. The Spanish case suggests how this chain of PA relationships produces the budgetary and economic statistics that are employed in the European Semester.

In the case of Spain, the provision of budgetary information to the EU begins with Spanish law (Ministerial Order ORDEN HAC/2283/2003) that requires the National Audit Office, which is a unit in the national Ministry of Finance (MOF), to collect budgetary data from the 17 ACs. Each AC through its ministry of finance is responsible for producing a set of public financial accounts. Each regional ministry of finance contains a regional audit office charged with that task. Spanish law delegates to the National Audit Office the power to audit central government and social security accounts, but restricts the auditing of regional accounts to these regional auditing offices. In the AC of Valencia, this unit is the Valencia Audit Office, which gathers 
data from the various government and publicly funded units in the region, such as the regional Ministry of Health. There also exists both a National Court of Auditors and regional courts of auditors that are responsible for examining and ensuring the credibility of the data generated by the national and regional ministries of finance' audit offices. The Valencia Audit Office submits its data four times a year to the National Audit Office through the Standardized Questionnaire. The National Audit Office then translates these public accounts figures into the ESA national accounts framework. These data are then submitted to the National Statistical Institute, which reviews and enters the data in the Commission's biannual reporting forms, and then advances these forms to Eurostat. Finally, EU Council Regulation 2011/85/EU, Spain's General Public Accounting Plan, and that of Valencia require that these public accounts figures include expenditure data that reflect accrual accounting principles. Expenditures are thus counted in the year they are formally recognized to be obligated on an annual basis in that year's budgetary accounts. Expenditures obligated but not formally recognized are included in extra-budgetary accounts, which are not recorded in the government's annual budgetary expenditure reports and counted in its deficit calculation. After these expenditures are formally recognized, they are then entered into the region's regular public accounts. Nevertheless, these formal rules and procedures were not sufficient to prevent severe irregularities from emerging in the Spanish statistics reported to Eurostat.

\section{2. 'Severe Irregularities' in Spanish Statistics}

In May 2012, Spain's National Statistical Institute informed Eurostat that the 2011 deficit figure of 8.5 percent of GDP it submitted in Spain's March 2012 biannual report needed to be increased by .4 percent. The Institute indicated that it had identified unreported budget expenditures in the 
ACs of Madrid and Valencia. Eurostat incorporated this revision in the October 2012 biannual report, which helped increase Spain's 2011 deficit to 9.4 percent of GDP. In June 2012, Eurostat initiated a series of on-site 'methodological' visits to investigate the cause of the revisions, as authorized by Regulations 479/2009 and 679/2010, and Commission Delegated Decision 2012/678/EU. Eurostat found that Madrid's accounts were inaccurate, but accepted that these errors were unintentionally entered. In the case of Valencia, however, Eurostat discovered extensive intentional misreporting and underreporting of health expenditures of $€ 1.893$ billion between 2007 and 2011.

Eurostat's investigation revealed a host of 'severe irregularities' that contributed to the breakdown in the PA monitoring system that Spain established to meet its EDP reporting requirements (European Commission 2015a). The Valencia Audit Office failed to record health expenditures in their proper accounts, in a manner consistent with Spanish and regional accrual accounting principles. The Audit Office ignored recommendations from the regional audit office and the regional ministry of health and failed to record expenditures in their proper accounts for five years, during which time none of these obligations were paid. The Audit Office then submitted its falsified information to the National Statistics Institute, which reported inaccurate expenditure and deficit figures to Eurostat. Oversight national and regional institutions were either ignored, uninformed, or powerless to control Valencia's behavior. Reflecting upon Spain's broken surveillance process, an official in the Directorate-General for Economic and Financial Affairs (DG ECFIN) declared that 'when it comes to budgetary statistics, the national statistical institutes are in the position of gathering asymmetric information vis-à-vis the government. So a government determined to cheat, could at least for a time, get away with it. ${ }^{2}$ 
Valencia's motivation for hiding its expenditures was rooted in the TEU's requirement that a member state's deficit and debt figures would be based on a general government calculation. This created adversarial PA relations over asymmetric information within the member states, as central governments necessarily began monitoring their subunits with greater attention. In 2001, Spain enacted an internal stability pact, followed by the Organic Law of 2012 on Budgetary Stability and Financial Sustainability, and the addition of Article 135.1 to Spain's constitution in 2012 created in compliance with Treaty on the Functioning of the European Union. These laws progressively attempted to constrain AC spending through spending, deficit, and debt ceilings, enforced by sanctions, though analyses of these rules indicate that they have been ineffective in controlling AC deficits (Almendral 2013a, 2013b; Howarth and Rommerskirchen 2013). Valencia's manipulations of statistics represented an attempt to evade these restrictions.

The Spanish government discovered the Valencia Audit Office's misreporting in 2012. That year, the government created a Special Payment Mechanism (SPM) to assume the collected commercial payments in arrears to suppliers for of all of Spain's ACs and municipal governments. The ministries of finance of these governments were required to disclose their fiscal deficiencies by submitting invoices their unpaid bills to the central Ministry of Finance, in exchange for relieving them of these payments. As the Valencia Audit Office was a unit in Valencia's regional ministry of finance, the ministry was aware of these unpaid expenditures and included them in the AC's invoices sent to the national MOF for funding through the SPM. Consequently, in order to benefit from the central government's payment of its outstanding obligations, the $\mathrm{AC}$ of Valencia was required to reveal its long-term, unpaid expenditures. As 
the SPM process progressed and Valencia's errors became known to the MOF, the MOF informed the National Statistical Institute that Spain's budgetary figures that were incorporated into its EDP reports to Eurostat were inaccurate. The Institute then notified Eurostat that the 2011 deficit needed to be revised upwards.

The discovery of these statistical discrepancies led the Commission in July 2014 to authorize Eurostat's formal investigation of Spain's deficits and debt figures. The Six Pack Directive 2011/85/EU outlined the new investigatory procedures the Commission could apply, including its right to interview 'any person directly or indirectly involved in compiling deficit and debt data, who agrees to be interviewed,' at any level of government. According to the Commissioner then responsible for Eurostat and European statistics, Algirdas Ŝemeta, 'The quality and credibility of European Statistics is not something the Commission is willing to compromise on. We depend on sound data to make sound decisions, and reliable statistics for evidence-based policy making' (European Commission 2014). Subsequently, a detailed report drafted by Eurostat and submitted by the Commission to ECOFIN declared that the Valencia Audit Office actively engaged in the misrepresentation of Valencia's expenditures.

\subsection{Spain's Response and ECOFIN's Financial Sanction of Valencia}

Spain defended itself against the Commission's investigation and reports by filing an action on 14 September, 2014 with the General Court of the European Court of Justice and by submitting its own rejoinder report to ECOFIN (Curia 2014; European Commission 2015b). Spain argued that Eurostat never questioned the data the National Statistical Institute submitted for the March EDP, and that Spain and the Institute should receive credit for immediately alerting Eurostat to 
the statistical discrepancies existing in the statistics. The data reflected neither grave negligence nor intent on the part of the Spanish government. More importantly, under the terms of Decision 2012/678, Eurostat lacked the authority to review data prior to December 2011. Eurostat's 'covert' investigation constituted an act of 'retroactivity,' by examining data dating to 1998 , far beyond the period covered in the 2012 EDP reports. This meant that the legitimate investigation was necessarily limited in scope and that penalties could only be imposed for the National Statistical Institute's 2011 data. Furthermore, member states often revised their data, so Spain should not be punished for what 'is standard practice in the majority of countries.' Finally, Spain's notification to Eurostat came in sufficient time to avoid any compromise to the EDP process applied to Spain; there was no 'detrimental effect at all,' none that would affect the Commission's surveillance ability 'to identify gross errors,' as called for the TEU. Of the $€ 1.893$ billion in missing expenditures identified by Eurostat covering the period 2007-2012, only $€ 862$ million could be attributed to 2011, the year in question, or just .08 percent of that year's GDP.

On 13 July, 2015, ECOFIN acted on the Commission's reports and issued Council Decision 2015/1289 that imposed a fine of €94.65 million on Spain for Valencia's 'serious negligence' leading to the 'manipulation of deficit data.' The fine was set on a reference value that levied the amount equal to 5 percent of the effect on the deficit for the years of the misrepresented data, which totaled of $€ 1.893$ billion, up to .2 percent of Spain's GDP in 2014. ECOFIN then, on Eurostat's recommendation, began 'taking into account' three extenuating circumstances that reduced the fine: first, the additionally discovered expenditures did not materially alter Spain's deficit for the EDP; second, the official deficit figure reported in the March biannual report was 
promptly corrected in the October report; and third, the manipulation of statistics represented the act of a regional authority, not Spain's national government. For these reasons, ECOFIN reduced the fine to $€ 18.93$ million.

\subsection{The General Court's Ruling and Spain's Reaction}

On 3 September, 2015, the General Court ruled in favor of the Commission (InfoCuria 2015). The Court agreed with the Commission's claim that by itself the investigatory process does not affect the 'legal position' of the member state, and that the Commission conducted the investigation in a manner consistent with Regulation 1173/2011. Spain could only challenge ECOFIN's decision and the fine, not the legality of the investigation. Regarding the fine, the Court ruled that ECOFIN applied the penalty in a manner consistent with TEU Article 261, such that it could 'annul, reduce or increase the fine so imposed.' The Court rejected Spain's assertion that the penalty should be set aside because this was 'the first decision of the Commission to initiate an investigation on the manipulation of statistics by a Member State' under the Six Pack, and that the investigation created harmful publicity that damaged its standing in international financial markets. The Court dismissed Spain's claim and ordered it to pay the fine set by ECOFIN.

Finally, the Commission's investigation, ECOFIN's decision, and the Court's ruling produced political controversy within Spain, and generated accusations between the central government and Valencia. Amid charges of mismanagement and corruption, the People's Party that governed Valencia suffered severe losses during the May 2015 elections. On 11 September, 2015, following the EU's General Court's ruling, the national Ministry of Finance ordered 
Valencia to pay the fine that had been imposed on the central government within two months. If it did not comply, the MOF would deduct those funds from the budgetary transfers normally sent to Valencia as part of Spain's regional financing.

\section{MEMBER STATE PUSHBACK: THE POLITICS OF ASYMMETRIC} INFORMATION IN THE MACROECONOMIC IMBALANCE PROCEDURE

The euro crisis and the Valencia case led to a reinforced EDP, but would the member states also permit the Commission to administer a similarly intrusive police patrol-like surveillance system to ensure the integrity of information submitted for the MIP? This section of the paper examines a Commission initiative to strengthen the statistical accuracy of MIP data through new regulations that would clarify and enhance Eurostat's authority over MIP statistics. The Commission's proposal to monitor asymmetric information, however, faced opposition from its member state principals in ECOFIN and the EP, as well as from and opposition from another surveillance agent, the European Central Bank.

\subsection{Eurostat's Proposed Regulations for "Quality" MIP Statistics}

In 2011, ECOFIN declared that the MIP 'must rely upon sound official statistics for inclusion in the scoreboard' (Council of the European Union, 2011). Following this declaration, Commissioner Algirdas Ŝemeta directed Eurostat to draft regulations that would grant the agency authority over MIP statistics similar to what it excised over EDP statistics. Ŝemeta, whose portfolio also included Taxation, Customs, Audit and Anti-Fraud as well as European statistics, was well-known in the Commission for being a strong enforcer of EU rules and ensuring the transparency of financial transactions. The resulting proposed regulation, $\operatorname{COM}(213) 342$, 
assigned Eurostat the police patrol powers to receive and assess the quality of the MIP data provided by the member states, conduct mission and investigatory methodological visits, express reservations on the quality of these data to the member state and ECOFIN's Economic Policy Committee, provide the data used for the MIP, amend the data, and, acting through the Commission, recommend fines against a member state not exceeding .05 percent of its GDP for the intentional or seriously negligent manipulation of statistics. Eurostat learned from its experience with Greece and other member states that without enhanced investigatory authority even country visits failed to reveal bad statistics. Though this new regulation, Eurostat would effectively receive the same authority over MIP data that it exercised over EDP statistics. As a senior Commission official with responsibility for Eurostat observed, 'Eurostat believes if the data can lead to fines it must be of the utmost quality, and therefore it must be controlled by Eurostat. If we put our stamp on it, we must have the power to check that it is good. So now if you introduce the MIP that can also lead to fines, then that data should also be subject to the same level of control and invasiveness that's in the EDP. ${ }^{3}$ Semeta successfully championed the proposal within the Commission, arguing that reliable and credible MIP statistics advanced the Commission's administration of the Semester. As an ECFIN official concluded, 'It is difficult to take the position 'I am against good statistics."

Despite Commission approval, the proposal met opposition from another agent in the MIP surveillance procedure, the European Central Bank (ECB), which viewed the proposed regulations as infringing on its administrative autonomy. Although the ECB plays no role in generating EDP statistics, it does produce statistics for the MIP's Net International Investment indicator and the Net External Debt auxiliary indicator (Hartlapp, Metz, and Rauh 2013). There 
are two major statistical data systems in Europe: the European Statistical System (ESS), which Eurostat administers, and the European System of Central Banks (ESCB), which the ECB administers under the authority of Regulation 2533/98. This regulation empowers the ECB to oversee the statistics generated by the various member state National Central Banks (NCB) and private financial institutions. Thus, the working relationships are more frequent and the institutional loyalties stronger between Eurostat and the national statistical institutes on the one hand, and the ECB and the NCBs on the other. The TEU and all subsequent statistics required for the EMU convergence process, the SGP, and the EDP rely upon the ESS. The MIP also relies heavily on the ESS, but the Net International Investment headline indicator and the Net External Debt auxiliary indicator rely on ESCB data.

After gaining approval from within the Commission, the regulation was submitted to the European Parliament and ECOFIN for their consideration in June 2013. In its 'Opinion' to the EP, the ECB declared that the Commission's proposal threatened the central bank's independence in governing ESCB statistics (European Central Bank 2013). The ECB argued that the proposal 'seems to establish parallel quality assessments,' while calling instead for preserving 'the already existing quality assurance arrangements of the ESS and the ESCB,' which 'should also be applied to the statistical data for the MIP.' Noting that the responsibility for generating MIP statistics are 'shared,' the ECB recommended that the coordination for the 'close cooperation' between the two systems should take place in the Committee on Monetary, Financial, and Balance of Payments Statistics (CMFB). The CMFB is the only institution where all of Europe's statistical units, Eurostat, the national statistical institutes, NCBs, and the ECB come together. Established in 1991, the CMFB is the premier body for setting policy on 
statistical requirements and methodologies. The ECB suggested that a memorandum of understanding (MOU) could be created in the CFMB to clarify the "practical operational arrangements' between the two systems in the production of MIP statistics.

The EP Committee on Economic and Monetary Affairs' amendments to the draft regulation echoed concerns expressed by both the member states and the ECB. Adopted by the EP during the first reading of the legislation in March 2014, the amendments directed that the 'the institutional separation of the [ESCB] and the independence of [NCBs] should be respected, added the ECB to the ESS Group of Directors of Macroeconomic Statistics, called for 'close cooperation' between the ESCB and the ESS, recommended that the 'practical operational arrangements' be set by an MOU, and required consultation between the national statistical institutes with the NCBs in the production of member state MIP data. The amendments reflected member state interests by calling for the Commission's 'closer and more timely involvement' of the national parliaments and the EP in MIP statistical surveillance, with NSIs potentially called to participate in EP committee hearings. Eurostat would be required to provide the EP with provisional reports on investigatory missions, and final findings would be sent to the EP as well as ECOFIN. Significantly, the process for fining member states was extended and made more difficult to impose. The fine would consist of an interest-bearing deposit not exceeding .05 percent of GDP in the preceding year, and it would be 'a last resort,' and, in an important revision, require that the offending member state be proved to be one that 'has acted intentionally to misrepresent the MIP relevant data.' When the EP considered the proposal said a Eurostat official, 'they have it in their minds that the same sanctions [employed in the EDP] will be applied in the MIP. ${ }^{5}$ Furthermore, this misbehavior must be one that 'as a consequence has 
impacted on the ability of the Commission to make a true and fair assessment' (European Parliament 2014). Thus, these amendments would greatly strengthen the EP's role as a principal overseeing Eurostat's monitoring of the member states' asymmetric information.

For its part, ECOFIN has 'taken note' of the regulation and it 'welcomes close cooperation' of the ESS and the ESCB, yet has not formally read the proposal (Council of the European Union 2013). Nevertheless, as Thyssen's cabinet officer noted, the member states view the EDP and MIP data as serving different purposes. '[The proposal] is mostly blocked at the level of the member states in the Council. Their argument is that [unlike the EDP's deficits and debt targets]...the MIP is more open. You have the alert mechanism and the in-depth review; it's not just that number that leads to the opening of a procedure that can lead to a fine. Thus, there is no

particular reason why these data should be subject to that level of invasiveness. ${ }^{6}$ As a consequence, the member states support a surveillance system that offers less rigorous controls over their statistical information.

\subsection{Current Status of the Proposal}

The Commission is reluctant to press the legislation forward with either the EP or ECOFIN. In lieu of the regulation, Eurostat responded by entering into an MOUs with the ECB in 2015, while creating a CMFB task force on statistical quality involving the member state NSIs and NCBs. These arrangements encourage cooperation in the development of MIP data, but they reified the ECB's institutional roles in overseeing its separate data stream employed in the MIP.

\section{DISCUSSION AND CONCLUSION}


These research findings illustrate the challenges of managing the multilevel PA aspects of asymmetric fiscal, economic, and social information in the EU. This study argues that prior to the Greek and euro crises the member states preferred a looser fiscal surveillance regime, akin to the PA notion of fire alarm. Having some surveillance system in place suggested their credible commitment to controlling the negative spillover effects of noncompliant behavior, with relatively limited intrusion on member state budgetary autonomy. The Greek crisis that stemmed from hidden information and its association with the debt crisis significantly altered the member states' willingness to adopt Commission recommendations to create an enhanced police patrol type of surveillance procedure for the SGP and EDP, one that tackled the asymmetric information advantages favoring the member state principals. Council regulations enacted in 2009 strengthening the Commission's authority to visit member states and scrutinize member state fiscal statistics were soon significantly augmented by the Six Pack. This legislation promotes deeper Europeanization and enhances the authority of the Commission in confronting the member states (Knill 2001; Featherstone and Radaelli 2003).

Thus, these crises strengthened the Commission's role in economic governance, specifically as analyzed here in its role in managing and ensuring the transparency of critical asymmetric member state information (Ellinas and Suleiman 2011; Chang 2013b; Bauer and Becker 2014a, 2014b, 2016; Dehousse 2015; Savage and Verdun 2015). The Six Pack granted the Commission the right to conduct investigations of member state administrative practices as they applied to fiscal statistics, the right to review the fiscal data and transactions of all levels of government within a member state, and the right to sanction member states with financial penalties. As a DG Secretariat-General official observed, 'If you look at it from a sovereignty perspective, we're 
interfering with what you could consider to be national governance. Here comes a supranational authority and does not address the central state, which is the main interlocutor with the EU, but can interfere directly with regional authorities. ${ }^{7}$ A DG ECFIN official involved with the case concurred, saying, 'We have established a precedent...The extent of potential cases is huge. ${ }^{8}$ In addition, in March 2015, ECOFIN amended Regulation 223/2009 to enhance the independence and professionalism of the member state NSIs, which worked closely with Eurostat in developing the European Statistical System that governs EU statistics. This legislation promotes Europeanization, offers the Commission the opportunity to scrutinize the statistical activities of the member states, and helps build networks and epistemic communities among European statisticians. In the Valencia case, it was Spain's National Statistics Institute that alerted Eurostat to the discrepancies in that country's statistics. The ruling against Valencia advanced Eurostat's authority with the member states regarding their statistics. Because of Valencia, as a senior Eurostat official deeply involved in the case explained, "We now have the power to investigate and recommend fines. Member states have realized they can be fined. Now they comply. After Valencia, everyone understood this can happen to them as well. So they are much more cooperative in giving even confidential data to the statistical offices. ${ }^{9}$

Nevertheless, even as the Valencia case represents the assertiveness of supranational agencies, the politics of asymmetric information also reflect the assertion by the EU's principals to exert their intergovernmental authority to restrict the Commission's initiatives when they regard it in their interests to do so (Dinan 2014; Puetter 2012; Bickerton et al 2014; Hodson 2013; Rittberger 2014; Schimmelfennig 2015). The MIP presented the Commission with an important opportunity to expand its prerogatives through Eurostat's oversight of the asymmetric 
information it obtained from the member states. A Eurostat official recalled, 'We would like to allow for the possibility of methodological visits or sanctions... With this proposal, we have more elements to strengthen the process and make sure the data are credible. ${ }^{10}$ The Parliament, however, revised Eurostat's proposal by reducing its investigatory powers, limiting its ability to recommend financial penalties, and by requiring Eurostat to report to the Parliament. In the bureaucratic competition between the two agents, Eurostat and the ECB, the Parliament ruled in favor of the ECB, permitting it to maintain its separate control over statistical information. ECOFIN has yet to act formally on the proposal, but has signaled its lack of interest in strengthening Eurostat's authority over member state statistics. Thus, while the member states supported a stronger police patrol monitoring of asymmetric information for the EDP, they expressed their preference for a relatively less restrictive fire alarm monitoring of member state information for the MIP.

In terms of economic governance, the politics of asymmetric information reflect the current status of the shifting power relationships between the member states and EU institutions as a result of the euro crisis. ECOFIN approved the Commission's entrepreneurial initiatives for greater authority over the member states in the effort to overcome asymmetric information barriers. The member states conceded that obtaining credible fiscal and economic information serves as a necessary condition for an effective fiscal and economic EDP surveillance system. The member states and the Parliament's experiences with the MIP differ from those of the EDP. The MIP has yet to be viewed as contributing to the type of economic and political crises that stemmed from the breakdown in Greek statistics (Zeitlin and Vanhercke 2014). Consequently, the member states and Parliament have elected to rely upon an MIP surveillance process that 
operates without the assurance of statistics as reliable as those in the EDP. What remains to be seen is whether at some point the MIP's alert mechanism and In-Depth Reviews may be compromised by this decision on asymmetric information, leading the EU's principals to delegate more authority to their agents in the Commission.

\section{RESEARCH NOTE}

In addition to analyzing the legislative treatment and administration of information, this study's findings rely upon interviews conducted during the fall of 2015 with 16 senior Commission officials in the Secretariat-General, ECFIN, Eurostat, and the Cabinet of the Commissioner for Employment, Social Affairs, Skills and Labor Mobility. Interviewees requested and were assured anonymity.

1. Interview with official in Commissioner Thyssen's Cabinet, 16 October 2015.

2. Interview with DG ECFIN official, 15 October 2015.

3. Interview with official in Commissioner Thyssen's Cabinet, 16 October 2015.

4. Interview with DG ECFIN official, 15 October 2015.

5. Interview with Eurostat official, 2 October 2015.

6. Interview with official in Commissioner Thyssen's Cabinet, 16 October 2015.

7. Interview with DG Secretariat-General official, 23 September 2015.

8. Interview with DG ECFIN official, 15 October 2015.

9. Interview with Eurostat official, 7 September 2015.

10. Interview with Eurostat official, 7 September 2015.

\section{REFERENCES}

Almendral, V.R. (2013a) 'Curbing the deficit in Spain and its autonomous communities: A constitutional conundrum,' Bij De Buren TvCR January: 68-77.

Almendral, V.R. (2013b) 'The Spanish legal framework for curbing the public debt and the deficit,' European Constitutional Law Review 9: 189-204.

Bauer, M. and Becker, S. (2014a) 'The unexpected winner of the crisis: The European Commission's role in policy execution,' Journal of European Public Policy 12(2): 217-36. 
Bauer M. and Becker, S. (2014b) 'Debate: From the front line to the back stage-How the financial crisis has strengthened the European commission,' Public Money \& Management, 1-3 May.

Bauer M. and Becker, S. (2016) 'Absolute gains are still gains: Why the European Commission is a winner of the crisis, and unexpectedly so. A rejoinder to Eugénia da Conceição-Heldt,' Journal of European Integration 38(1): 101-106.

Bickerton, C.J., Hodson, D. and Puetter, U. (2014) 'The new intergovernmentalism: European integration in the post-Maastricht era,' Journal of Common Market Studies 53(4): 703-722.

Chang, M. (2013a) 'Constructing the Commission's six-pack proposals: Political leadership thwarted?' in M. Change and J. Monar (eds) The European Commission in the Post-Lisbon Era of Crises, Peter Lang Publishers, 147-169.

Chang, M. (2013b) 'Fiscal policy coordination and the community method,' Journal of European Integration 35(3): 255-269.

Conceição-Heldt, E. (2016) 'Why the European Commission is not the "unexpected winner" of the Euro crisis: A comment on Bauer and Becker,' Journal of European Integration 38(1): 95100 .

Council of the European Union. (2011) 'Council conclusions on an early warning scoreboard for the surveillance of macroeconomic imbalances,' 8 November.

Council of the European Union. (2013) 'Council conclusions on EU statistics,' 15 November.

Curia. (2014) 'Action brought on 22 September 2014, Spain v. Commission,' 22.9.24, Case T$676 / 14$.

Dehousse, R. (2015) 'The new supranationalism,' Paper Prepared for ECPR General Conference, Montreal.

Dinan, D. (2014) 'Governance and institutions: The unrelenting rise of the European Parliament,' Journal of Common Market Studies 52(Annual Review) 109-124.

Ellinas, A. and Suleiman, E. (2011) 'Supranationalism in a transitional bureaucracy: the case of the European Commission,' Journal of Common Market Studies 45(5): 923-47.

Essi, S. and Stiglbauer, A. (2011) 'Prevention and correction of macroeconomic imbalances: the excessive imbalance procedure,' Monetary Policy \& the Economy Q4/11: 99-113.

European Central Bank. (2013) 'Opinion of the European Central Bank,' 10.10.13, CON/2013/72). 
European Commission. (2014) 'Commission opens investigation into statistical reporting in Valencia,’ 11.7.2014, IP/14/822.

European Commission. (2015a) 'Report from the Commission,' 7.5.2015, COM(2015)211 Final.

European Commission. (2105b) 'Annex to the Commission report,' 7.5.2015, COM(2015)211 Final.

European Parliament. (2014) 'Amendments adopted by the European Parliament,' 11.3.14. http://www.europarl.europa.eu/sides/getDoc.do?pubRef=-//EP//TEXT+TA+P7-TA-2014$\underline{0181+0+\mathrm{DOC}+\mathrm{XML}+\mathrm{V} 0 / / \mathrm{EN}}$

Featherstone, K. and Radaelli, C. (eds) (2004) The Politics of Europeanization, New York: Oxford University Press.

Gandrud, C. and Hallerberg, M. (2016) 'Statistical agencies and responses to financial crises: Eurostat, bad banks, and the esm,' West European Politics Forthcoming.

Gren, J., Howarth, D. and Quaglia, L. (2015) 'Supranational banking supervision in Europe: The construction of a credible watchdog,' Journal of Common Market Studies, 53(1): 1-19.

Hartlapp, M., Metz, J. and Rauh, C. (2013) 'Linking agenda setting to coordination structures: bureaucratic politics inside the European Commission,' Journal of European Integration 35(4): 425-441.

Hawkins, D., Lake, D., Nielson, D., and Tierney, M. (eds) (2006) Delegation and Agency in International Organizations. New York: Cambridge University Press.

Hodson, D. (2009) 'Reforming EU economic governance: A view from (and on) the principalagent approach,' Comparative European Politics 7(4): 455-475.

Hodson, D. (2013) 'The little engine that wouldn't: Supranational entrepreneurship and the Barroso Commission,' Journal of European Integration 35(3): 301-314.

Hodson, D. (2014) 'Eurozone governance: Recovery, reticence and reform,' Journal of Common Market Studies 52(Annual Review); 186-201.

Howarth, D. and Rommerskirchen, C. (2013) 'Panacea for all times: the politics of the German stability culture,' West European Politics 36(4): 750-770.

InfoCuria. (2015) 'Order of the General Court,' 3.9.15, Case T-676/14. http://curia.europa.eu/juris/document/document.jsf?text=\&docid=167541\&pageIndex=0\&doclan $\mathrm{g}=\mathrm{EN} \& \operatorname{mode}=1 \mathrm{st} \& \operatorname{dir}=\&$ occ $=$ first\&part $=1 \& \mathrm{cid}=625246$ 
Kiewiet, R. and McCubbins, M. (1991) The Logic of Delegation, Chicago: University of Chicago Press.

Knill, C. (2001) The Europeanization of National Administration: Patterns of Institutional Change and Persistence. New York: Cambridge University Press.

Mabbett, D. and Schelkle, W. (2014) 'Searching under the lamp-post: The evolution of fiscal surveillance,' London School of Economics European in Question Paper Series, No. 75.

Majone, G. (2001) 'Two logics of delegation: Agency and fiduciary relations in EU governance,' European Union Politics 2(1): 103-122.

McCubbins, M. and Schwartz, T. (1984) 'Congressional oversight overlooked: Police patrol versus fire alarms,' American Journal of Political Science 2(1): 165-79.

Miller, G.J. (2004) 'The political evolution of principal-agent models,' Annual Review of Political Science 8:203-225

Moschella, M. (2014) 'Monitoring macroeconomic imbalances: Is EU surveillance more effective than IMF surveillance?' Journal of Common Market Studies 52(5): 1273-1289.

Pollack, M. (1997) 'Delegation, agency, and agenda setting in the European Community.' International Organization 51(1): 99-134.

Puetter, U. (2012) 'Europe's deliberative intergovernmentalism: The role of the Council and European Council in EU economic governance,' Journal of European Public Policy 19(2): 161178.

Rittberger, B. (2014) 'Integration without representation? The European Parliament and the reform of economic governance in the EU,' Journal of Common Market Studies 52(6): 11741183.

Savage, J. (2005) Making the EMU: The Politics of Budgetary Surveillance and the Enforcement of Maastricht. Oxford: Oxford University Press.

Savage, J. (2006) 'Member state budgetary transparency in the economic and monetary union,' in C. Hood and D. Heald (eds), Transparency: The Key to Better Governance? New York: Oxford University Press.

Savage, J. and Verdun, A. (2015) 'Strengthening the European Commission's budgetary and economic surveillance capacity since Greece and the Euro area crisis: A Study of Five Directorates-General,' Journal of European Public Policy, 23(1): 101-118.

Schelkle, W. (2005) 'The political economy of fiscal policy co-coordination in emu: From disciplinarian device to insurance arrangement,' Journal of Common Market Studies 43(2): 371391. 
Schelkle, W. (2009) 'The contentious creation of the regulatory state in fiscal surveillance.' West European Politics 32(4): 829-46.

Schimmelfennig, F. (2015) 'Liberal intergovernmentalism and the Euro area crisis' Journal of European Public Policy 22(2): 177-195.

Schuknecht, L. (2004) 'EU fiscal rules: Issues and lessons from political economy,' European Central Bank Working Paper, No. 421.

Tallberg, J. (2002) 'Delegation to supranational institutions: Why, how, and with what consequences?' West European Politics 25(1): 23-46.

Verdun, A. (2015) 'A historical institutionalist explanation of the EU's responses to the Euro area financial crisis.' Journal of European Public Policy 22(2): 219-237.

Zeitlin, J. and Vanhercke, B. (2014) 'Socializing the European semester?: Economic governance and social policy coordination in Europe 2020' Swedish Institute for European Policy Studies, Report 7. 